\title{
高マンガン鋼溶接部の高温割れ発生傾向*
}

\author{
一主として母材の Si およびP含量の影響について一
}

\author{
木 俣 登** 安藤 精一***
}

\section{Hot Cracking Susceptibility of Austenitic Manganese Steel Welds*}

-Mainly on Effects of Silicon and Phosphorus in Base Metal-

by Noboru Kimata** and Seiichi Ando***

\begin{abstract}
To investigate the effect of silicon and phosphorus content in base metal on the hot cracking susceptibility of welds, slit type cracking tests and angle expanding type (the modified Murex type) cracking tests were carried out. The materials used here were two series of austenitic manganese steel base metal, one varying in silicon $(0.18-1.85 \%)$ and the other in phosphorus content $(0.035-0.086 \%)$, and $16 \mathrm{Mn}-16$ Cr type electrodes. $17 \mathrm{Cr}-7 \mathrm{Ni}$ stainless steel (AISI 301 type) base metal and $16 \mathrm{Mn}-16 \mathrm{Cr}, 19 \mathrm{Gr}-9$ $\mathrm{Ni}$ and $25 \mathrm{Cr}-20 \mathrm{Ni}$ type electrodes were also used for comparative test with austenitic manganese steel base metal which had normal silicon and phosphorus content.

In the slit type cracking test on Si series base metal, a few micro cracks were observed in weld heataffected zone (HAZ), but they seldom extended into the weld metal even if $1.86 \%$ Si base metal was used, while conspicuous cracks were observed in the HAZ and weld metal when the phosphorus content of base metal exceeded $0.065 \%$ as reported previously by the authors.

In the angle expanding type cracking test, the cracking susceptibility of weld bead increased as increasing the silicon as well as phosphorus content of base metal. It is also substantially affected by the difference of $0.025 \%$ in phosphorus content of the electrodes,
\end{abstract}

\section{1.まえがき}

著者らはさきに高マンガン鋼の溶接性におよぼす母材 中のPの影響について報告し1)，溶接部の高温割れにつ いても一部言及した。また高マンガン鋼用溶接棒の䯩温 割れ発生傾问について報告し2，溶接棒（溶着金属）の 化学成分の影響について検討した、こてでは母材の $\mathrm{Si}$ 今量の異なる 7 種の高マンガン鋼を母材とし，16Mn-16 $\mathrm{Cr}$ 型溶接棒を用いて溶接したビード（溶接金属）およ び母材熱影響部の高温割れ発生傾向を明らかにし，また 母材のP含量を異にする場合についてもさらに検討を加 え, 両者の結果を比較した. この他通常のPおよび Si 含量の高マンガン鋼を母材しする溶接金属（溶接棒： $16 \mathrm{Mn}-16 \mathrm{Cr}$ および $19 \mathrm{Cr}-9 \mathrm{Ni}$ 型) の高温割れ発生傾向 を, 従来多くの研究 ${ }^{3)}$ が行なわれている $\mathrm{Cr}-\mathrm{Ni}$ ステン レス鋼を母材とする場合と比較した。これらの場合，割

* 原稿受付 昭和46年 月 日（昭和44年梑季全国大会にて笔表）

** 正 員 鉄道技術研究所 Member, Railway Technica] Research Institute, JNR

*** 正 員 日本大学生産工学部 Member, College of Industrial Technology, Nihon University
れ試験は主として展開式すみ肉溶接割れ試験によった が，一部スリット型を併用した。な抢 $\mathrm{Si}$ は溶鋼の流動 性を增大し，高マンガン鋼の鋳造欠楩の防止に有効と考 えられている。

\section{2. 实 験 方 法}

\section{1 供試材}

母材の化学成分を Table 1 に示した. Table 1(a) で Si 1〜7 鎆は $\mathrm{Si}$ 含量を, また $\mathrm{P} 1 \sim 7$ 鋼は $\mathrm{P}$ 含㻎を異 にする高マンガン鋼である，てれらはつぎの M1 鈵よ 亡すにいずれ手砂型に鋝込み，押湯を除いて $1050^{\circ} \mathrm{C} に$ 1.5 2 hr 加熱急冷の水じえ処理を施た後, 切削加工 し，展開式すみ肉およびスリット型各溶接割れ試験片の 所定寸法に仕上げて使用した. ただし P7 鋼はX楾子 イクロアナライザーにより，Pを多く含む偏析物の分析

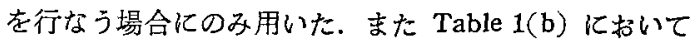
M1 および S1 鋼はステンレス鋼との比較試験に使用L たもので, 前者は通常のPおよび $\mathrm{Si}$ 含量を有する高マ ンガン鋼, また後者は AISI 301 型 $\mathrm{Cr}-\mathrm{Ni}$ ステンレス 鍋板 (板厚 $15 \mathrm{~mm}$ ) で, 切断切削し, 展開式すみ肉溶 
Table 1 Chemical composition of base metals used

a) For test on effect of silicon and phosphorus

\begin{tabular}{|c|c|c|c|c|c|c|c|c|c|}
\hline \multirow{2}{*}{\multicolumn{2}{|c|}{ No. }} & \multicolumn{8}{|c|}{ Chemical composition $(\%)$} \\
\hline & & $\mathrm{C}$ & Si & $\mathbf{M n}$ & $\mathrm{P}$ & $\mathbf{S}$ & $\mathrm{Cu}$ & As & Sn \\
\hline $\mathbf{S i}$ & 1 & 1.06 & 0.18 & 12.58 & 0.027 & 0.007 & 0.17 & 0.035 & 0.028 \\
\hline$" \prime$ & 2 & 1.14 & 0.35 & 13.30 & 0.028 & 0.009 & 0.17 & 0.030 & 0.034 \\
\hline$"$ & 3 & 1.07 & 0.59 & 12.98 & 0.025 & 0.009 & 0.19 & 0.026 & 0.033 \\
\hline$n$ & 4 & 1.13 & 0.80 & 23.31 & 0.027 & 0.006 & 0.16 & 0.034 & 0.039 \\
\hline$" \prime$ & 5 & 1.06 & 0.92 & 12.87 & 0.024 & 0.008 & 0.20 & 0.035 & 0.038 \\
\hline$" \prime$ & 6 & 1.08 & 1.39 & 12.77 & 0.027 & 0.008 & 0.19 & $0.027^{\circ}$ & 0.038 \\
\hline$" \prime$ & 7 & 1.07 & 1.85 & 13.45 & 0.026 & 0.013 & 0.17 & 0.024 & 0.037 \\
\hline $\mathbf{P}$ & 1 & 1.08 & 0.40 & 12.82 & 0.035 & 0.012 & 0.21 & 0.029 & 0.031 \\
\hline$" \prime$ & 2 & 1.06 & 0.37 & 12.42 & 0.041 & 0.011 & 0.16 & 0.031 & 0.031 \\
\hline$"$ & 3 & 1.08 & 0.40 & 13.08 & 0.052 & 0.011 & 0.21 & 0.027 & 0.031 \\
\hline$" \prime$ & 4 & 1.12 & 0.26 & 13.12 & 0.064 & 0.010 & 0.23 & 0.023 & 0.034 \\
\hline$"$ & 5 & 1.09 & 0.32 & 13.18 & 0.073 & 0.011 & 0.22 & 0.023 & 0.035 \\
\hline$n$ & 6 & 1.12 & 0.28 & 13.45 & 0.086 & 0.013 & 0.22 & 0.020 & 0.030 \\
\hline $\mathbf{P}$ & 7 & 1.08 & 0.40 & 12.79 & 0.276 & 0.020 & 0.24 & - & - \\
\hline
\end{tabular}

b) For comparative test with $\mathrm{Cr}-\mathrm{Ni}$ stainless steel

\begin{tabular}{c|c|c|c|c|c|c|c|c}
\hline \multirow{2}{*}{ No. } & \multicolumn{10}{c}{ Chemical composition $\%$} \\
\cline { 2 - 7 } & $\mathrm{C}$ & $\mathrm{Si}$ & $\mathrm{Mn}$ & $\mathrm{P}$ & $\mathrm{S}$ & $\mathrm{C}$ & $\mathrm{Cr}$ & $\mathrm{Ni}$ \\
\hline $\mathrm{M} \mathrm{1}$ & 1.06 & 0.39 & 12.60 & 0.033 & 0.010 & 0.14 & - & - \\
$\mathrm{S}$ & 0.10 & 0.35 & 1.04 & 0.028 & 0.011 & 0.22 & 17.63 & 7.08 \\
\hline
\end{tabular}

Table 2 Chemical composition of electrodes used

\begin{tabular}{|c|c|c|c|c|c|c|c|c|c|c|c|c|}
\hline \multirow{2}{*}{ No. } & \multirow{2}{*}{ Type } & \multicolumn{11}{|c|}{ Chemical composition $(\%)$} \\
\hline & & C & Si & $M n$ & $P$ & $\mathbf{s}$ & $\mathrm{Cu}$ & $\mathrm{Cr}$ & $\mathrm{Ni}$ & As & $\mathrm{sin}$ & $\mathbf{N}$ \\
\hline $1 \mathrm{a}$ & $16 M n-16 C_{r}$ & 0.09 & 0.65 & 15.50 & 0.014 & 0.007 & 0.07 & 16.45 & 2.27 & 0.020 & 0.029 & 0.13 \\
\hline $1 \mathrm{~b}$ & $"$ & 0.15 & 0.51 & 15.55 & 0.040 & 0.007 & 0.06 & 16.14 & 2.35 & 0.024 & 0.032 & 0.20 \\
\hline 2 a & $19 \mathrm{C}_{\mathrm{r}-9 \mathrm{Ni}}$ & 0.07 & 0.36 & 1.61 & 0.032 & 0.007 & 0.07 & 20.97 & 9.48 & - & - & 0.07 \\
\hline $2 \mathrm{~b}$ & $25 \mathrm{Cr}-20 \mathrm{Ni}$ & 0.06 & 0.48 & 1.67 & 0.014 & 0.017 & 0.06 & 25.5 & 20.0 & - & - & 0.06 \\
\hline
\end{tabular}

Note : No. 1a and $1 \mathrm{~b}$ used for test on silicon and phosphorus effect, and No. 1b, 2a and $2 b$ for comparative test with austenitic $17 \mathrm{Cr} .7 \mathrm{Ni}$ stainless steel

接割れ試験片として使用した.

つぎに供試溶接棒による溶着金属の化学成分を Table 2 に示した. こてで No. 1a および 1b 棒は主として P 含量の異なる $16 \mathrm{Mn}-16 \mathrm{Cr}$ 型溶接棒，また No. $2 \mathrm{a}$ 扰よ び $2 \mathrm{~b}$ 棒はそれぞれ JIS D308 および310型溶接棒で,

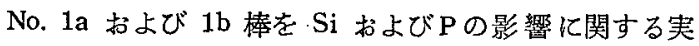
験に，また No. 1b，2a および $2 \mathrm{~b}$ 棒をステンレス鋼と の比較試験に用いた.なお棒径はいずれす $4 \mathrm{~mm}$ であ る.

\section{2：スリット型溶接割れ試験}

母材のP含量を変えた場合のスリット型溶接割れ試験 の結果についてはすでに報告1しており，ててでは母材 の $\mathrm{Si}$ 含量を変えた場合について実験を行なった。この 場合の溶接条件は P の場合1)之同一で, Fig. 1 亿示す ように長さ $80 \mathrm{~mm}$ のY型グルーブ（ルート間隔: 1.5

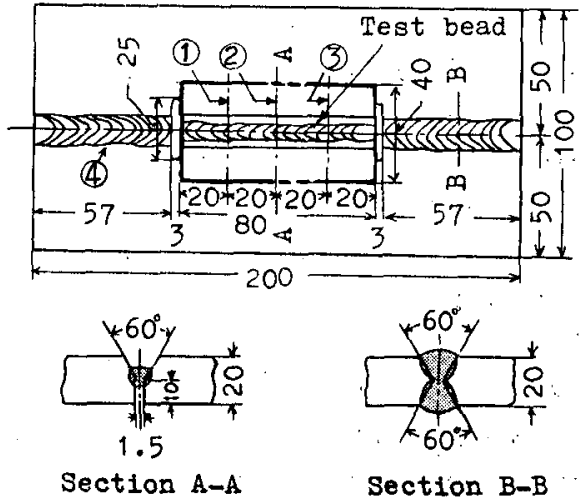

Fig. 1 Slit type cracking test specimen (unit $\mathrm{mm}$ ). (1), (2), (3), Crack inspected sections. 4: Weld for restraint 
$\mathrm{mm})$ 上に No. 1b 棒を用い, 溶接電流 $140 \mathrm{~A}$, 溶接速 度 $200 \mathrm{~mm} / \mathrm{min}$ でシングルビードを置いた. 試験は各 鋼について 2 回行なった. なお拘束溶接 (Fig. 1) にも No. 1b 棒を使用した.

溶接後試験ビードに対し，肉眼および染色滲透探傷剂 により表面の割れの, また肉眼により Fig. 1 に示す 3 ケ所の切断面について破面の割れ発生状態を調べた.

\section{3 展開式すみ肉溶接割れ試験}

\section{3 . 1 Si および P の影響に関する実験}

Si 1〜7 鋼および P1〜P6 鋼から $17 \times 75 \times 80(\mathrm{~mm})$ の大きさに製作した試験板 2 枚を 1 組として割れ試験機 に取り付け，前項に述べた主として P含量を異にする 2 種の $16 \mathrm{Mn}-16 \mathrm{Cr}$ 型溶接棒 (No. 1a および $1 \mathrm{~b}$ ) を用い て試験ビードを置いた. との場合の試験要領を Fig. 2 （a）に，また溶接条件および展開条件を Table 3 に示 す. 割れ率はビード表面に現われた割れ，および試験後 の強制破断面の酸化着色部（線状破面を呈する）につい てつぎにより求め, それぞれ「表面割れ率」および「破 面割れ率」とした。
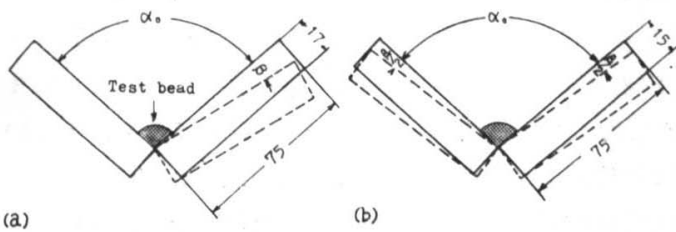

(b)

Fig. 2 Angle expanding type cracking test method (unit $\mathrm{mm}$ ).

Table 3 Expanding and welding conditions for angle expanding type cracking test

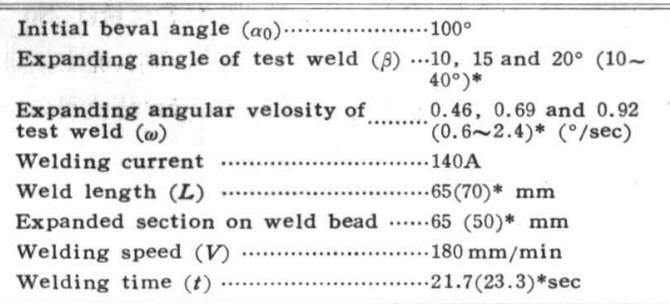

*) Figures in parenthesis show the case of comparative test with stainless steel

$$
\left(L_{c} / L_{0}\right) \times 100(\%)
$$

ここで $L_{c}$ は割れの長さで, 割れが連続せず 2 分されて いるような場合は，それらの長さの合計を用いた．また 分母の $L_{0}$ は $50 \mathrm{~mm}$ としたが，この值はクレータ部を 除く溶接長よりも若干短かい.

\section{3 .2 ステンレス鋼との比較試験}

この場合は通常のPおよび $\mathrm{Si}$ 含量の高マンガン鋼
$\mathrm{M} 1$ および $17 \mathrm{Cr}-7 \mathrm{Ni}$ 型ステンレス鋼 $\mathrm{S} 1$ を $15 \times 75 \times$ $85(\mathrm{~mm})$ の大きさに加工して母材とし, $16 \mathrm{Mn}-16 \mathrm{Cr}$, $19 \mathrm{Cr}-9 \mathrm{Ni}$ あるいは $25 \mathrm{Cr}-20 \mathrm{Ni}$ 型溶接棒を使用して試 験ビードを置いた．ここで溶接条件は前項の場合と同一 であるが, 展開は両開き式 (Fig. 2(b) 従来は片開き 式）とし, 比較的定常的な溶接の行なわれる部分にお いて展開を加えることとした. すなわち Fig. 5 中の説 明図に示すように, 溶接長 $70 \mathrm{~mm}$ のうちスタート側 5 $\mathrm{mm}$, クレータ側 $15 \mathrm{~mm}$ を除く長さ $50 \mathrm{~mm}$ の間にお いて展開を加え, 表面の割れおよび強制破断面の酸化着 色部について前項の場合と同様に表面および破面割れ率 を求めた. ただしここでは $L_{c}$ は展開を加えた部分にお ける割れの長さ, また $L_{o}$ には展開を加えた部分の長さ (50 mm) を用いた. なお Photo. 1 はとの場合に使用 した割れ試験装置を示す.

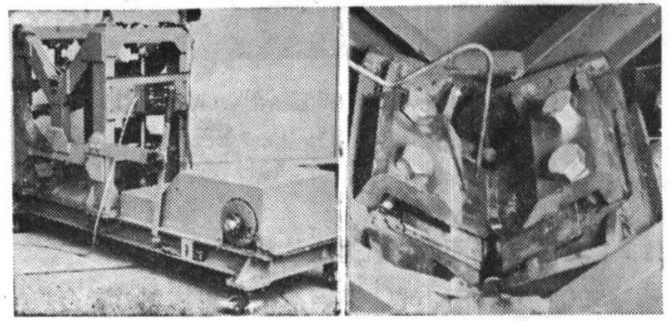

Photo. 1 Apparatus for angle expanding type cracking test

\subsection{X 線マイクロアナライザーによる分析}

高温割れ発生傾向におよぼす不純物元素などの影響を 明らかにするため, 割れの先端付近におけるそれらの濃 度分布を X線マイクロアナライザー (XMA) により求 める試みはいくつか行なわれている4) が, ここでは同様 な目的で一般の柱状晶の粒界および隣接するセルデンド ライトの境界付近に注目して $\mathrm{P}$ おび $\mathrm{Si}$ の分布を求め た.

使用した装置は日本電子製 JXA3A 型で， 2 元素同 時分析とし, 加速電圧は $20 \mathrm{kV}$ とした. なおビーム照 射位置と顕微鏡組織との関係を明らかにするため, 溶接 金属は塩化第 2 鉄, 母材は硝酸了ルコール溶液で軽く腐 食し, 分析後必要に応じ再度腐食して顕微鏡写真を撮影 した.

\section{3. 実験結果および検討}

\section{1 スリット型溶接割れ試験結果}

\section{1.1 ビード表面の割れ発生状態}

肉眼および染色滲透探傷剂による検査では, ビードお よび母材熱影響部に割れを認めなかった. ただしクレー タ割れはすべての試験ビードに生じていた．ビードの外 
観の一例を Photo. 2 に示す.

さきの報告 ${ }^{1)}$ では母材の $\mathrm{P}$ 含量を $0.025 \sim 0.085 \%$ の範 囲に 4 段階に変えた場合（供試溶接棒の $\mathrm{Si}$ および $\mathrm{P}$ 含 量はそれぞれ 0.59 およ゙ $0.025 \%) ， 0.065 \%$ より滲透探 傷剂により表面(ビードおよび熱影響部)に微細な割れを 検出し，またX線透過検査により，かなり明らかに内部 割れを検出している. しかし今回の実験における母材の $\mathrm{Si}$ 含量の範囲では，X線によっても割れは検出されな かった.

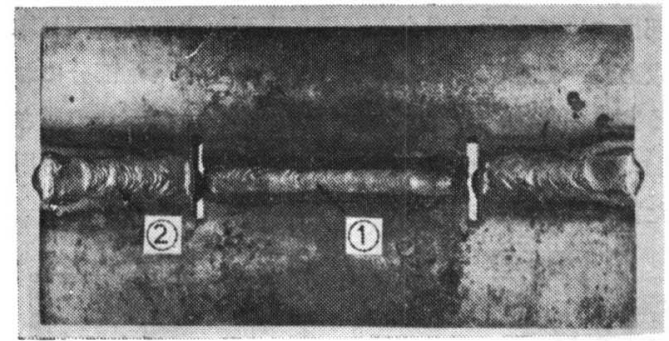

Photo. 2 Exterior view of bead weld in slit type cracking test. (1): Test bead, (2): Weld for restraint

\section{1 .2 切断面の割れ発生状態}

溶接部切断面において，母材溶接熱影響部の融合線付 近には微細な少数の割れを認める場合があり、これは $\mathrm{Si}$ 含量の多い Si 6 およよび Si 7 鋼を母材とするとき やや多い，ただしてれが溶接金属の内部にまで進展する ことは少なく，たとえ進展してあ Photo. 3 に示すよう に軽微である.なおさきの $\mathrm{P}$ 含量を変えた夷験1)では， $\mathrm{P}$ 含量 $0.065 \%$ 以上飞おいて切断面に母材熱影響部割れ およびこれに続く顕著なビード割れを認めている.

\section{2 展開式すみ肉溶接割れ試験結果}

展開式すみ肉溶接割れ試験の場合, ビードの表面割れ 率と破面割れ率を比較すると前者の方が一般に小さい

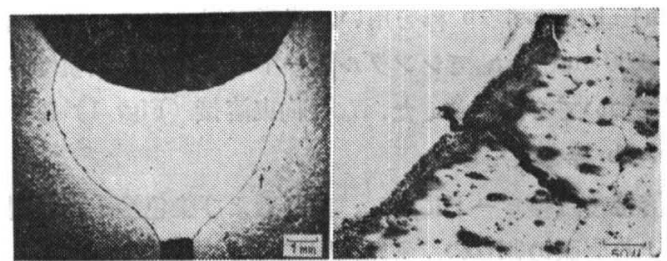

Photo. 3 Cracks observed on transverse section of bead weld in slit type cracking test specimen. (a): $\times 7 \quad(\times 1 / 2)$, (b): $\times 200(\times 1 / 2)$. Base metal: (a); $\mathrm{Si} 7$ $(1.85 \% \mathrm{Si}),(\mathrm{b})$; Si $6(1.37 \% \mathrm{Si})$. Files in photo. $3(\mathrm{a})$ show fine cracks in heataffected zone

が，その差は比較的少なく，ここでは主として破面割れ 率について述べるとととする.

\section{3 . 2 . 1 母材の $\mathrm{Si}$ 含量の影響}

この場合の破面割れ率と母材の $\mathrm{Si}$ 含量との関係を Fig. 3 亿示した. この種の曲線は, あし適当な展開角 度と $\mathrm{Si}$ 含量の範囲を与えれば, $\mathrm{Si}$ 含量の増大ととも に0から $100 \%$ ， あるいはこれに近い值まで変化する遷 移曲線となるであろうが，P含量の低い No. 1a 棒を使 用した場合, 展開角度 $\beta$ が $10^{\circ}$ では, 母材の $\mathrm{Si}$ 含量 $1.85 \%$ ( $\mathrm{Si} 7$ 鋼) でも割れの発生は見られず, 従ってま だ曲線の立上りは認められない，しかし $\beta$ を $15^{\circ}$ あるい は $20^{\circ}$ に大きくとると, $\mathrm{Si}$ 含量の増大ととあにかなり大 きい割れ率を示すようになり，それぞれ遷移曲線の下部 および上部が現われている.すなわち前者では $0.92 \%$ $\mathrm{Si}$ (Si 5 銅) から割れを生じ, また後者の場合は $\mathrm{Si}$ 含 量の低い範囲でも割れ率は高く, $0.59 \% \mathrm{Si}(\mathrm{Si} 3$ 鋼) で $100 \%$ 亿近い值を示すようになる.

これに対し $\mathrm{P}$ 含量の高い No. $1 \mathrm{~b}$ 棒 ( $\mathrm{Si}$ 含量は No. 1a 棒に比べてやや低い) を用いた場合, 割れ発生傾向 は一般に大きく, 上記の遷移曲線は No. 1a 棒使用の場

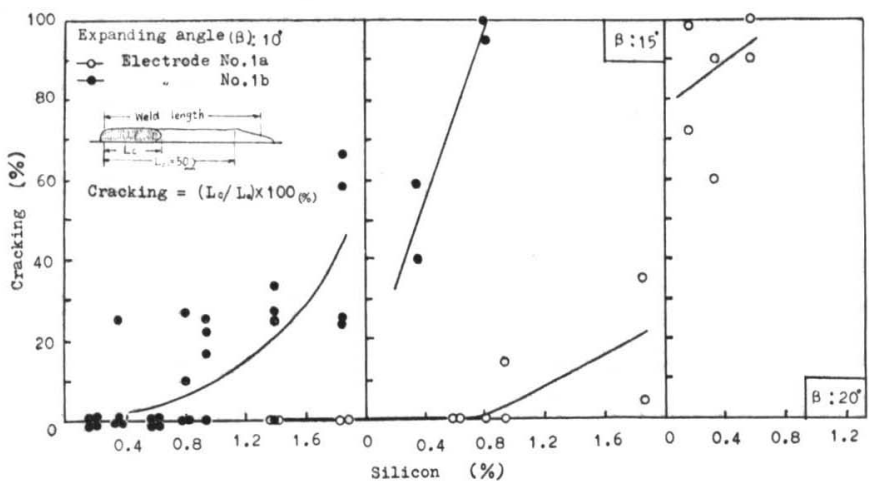

Fig. 3 Effect of silicon in base metal on cracking susceptibility of bead weld in angle expanding type cracking test 
合に比べてかなり左寄りとなり, 展開角度 $10^{\circ}$ ではその 下半分が，また $15^{\circ}$ ではおよそ上半分が現われている. すなわち展開角度 $10^{\circ}$ では, 母材の $\mathrm{Si}$ 含量 $0.35 \%(\mathrm{Si}$ 2 鋼) で一部の試験片に割れを生じ, $1.85 \% \mathrm{Si}(\mathrm{Si} 7$ 鋼)でおよそ25〜65\%の割れ率を示す. さらに展開角度 15 では母材が $0.35 \%$ Si (Si 2 鋼) でほぼ50\%, 0.80 $\% \mathrm{Si}$ (Si 4 鋼) で100\%近い割れ率を示す.

ビードの強制破断面には上記の酸化線状破面の他, 非 酸化線状破面を伴なう場合がかなりある. Photo. 4 は 表面および破面の割れの一例を示すあのであるが，（b ） においては酸化線状破面およびこれにつづき軽微な非酸 化線状破面（矢印の付近）が認められる.

つぎに Photo. 5 に母材および溶接棒にそれぞれ Si 7 鋼および No. 1a 棒を使用した場合の, ビード横断面に おける割れ発生状態の一例を示す（展開角度 : $15^{\circ}$, 破 面割れ率: $64 \%$ ). この割れはビード表面に現われた割 れの終端付近を切断した場合のもので, ピード表面に近

(a)

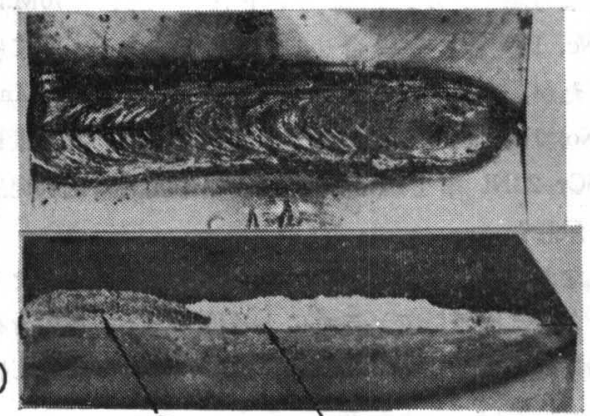

(1)

(2)
い等軸晶的な組織を示す部分は明らかでないが，それよ り下では柱状晶の粒界および一部セルデンドライトの境 界に沿って進行しているあのとみられる.

\subsection{2 母材の $\mathbf{P}$ 含量の影響}

破面割れ率におよぼす母材のP含量の影響を Fig. 4 に示す. P含量の低い No. 1a 棒を使用した場合, 母材 のP含量が $0.086 \%$ (P 6 鋼) であわずかに破面に割れ (酸化線状破面) を認めたに過ぎない. しかし展開角度 $15^{\circ}$ では $\mathrm{P}$ 含量の増大ととあに割れ率が増大し，0.064 $0.073 \%$ P (P 4 ないし P 5 鋼) より割れ率の遷移曲線 は急速な立上りを示す. さらに展開角度 $20^{\circ}$ では曲線は

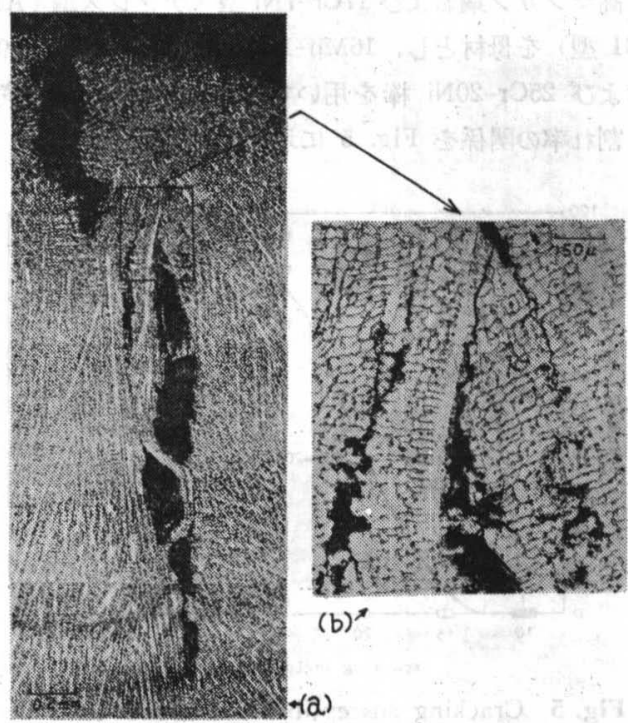

Photo. 5 Crack observed on transverse section of bead weld in angle expanding type cracking test, (a): $\times 50(\times 1 / 2)$, (b): $\times 200(\times 1 / 2)$. Electrolytically etched in oxalic acid solution. Base metal: Si 7, Electrode :No. 1a show oxidized and unoxidized inter-
dendritic columnar fracture, respectively

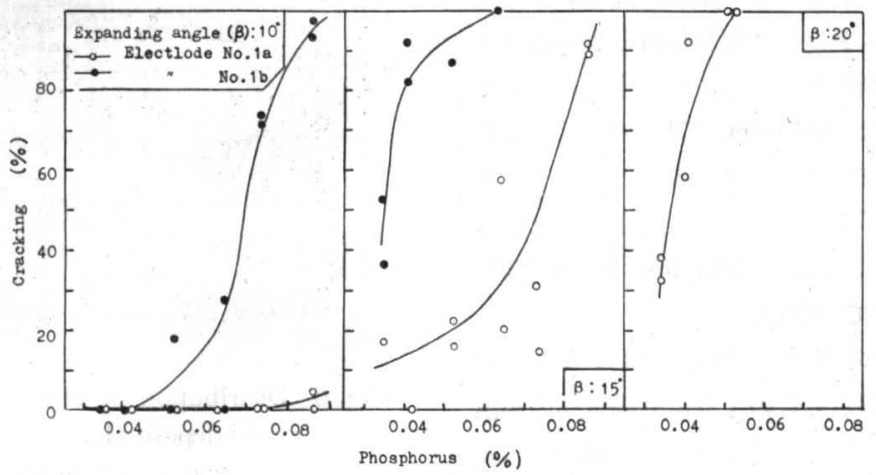

Fig. 4 Effect of phosphorus in base metal on cracking susceptibility of bead weld in angle expanding type cracking test. 
かなり左方に寄り，P含量 $0.052 \%$ で100\%の割れ率を示 す.

P含量の高い No. 1b 棒を使用すると, 母材の $\mathrm{Si}$ 含 量を変えた場合と同様に，No. 1a 棒を使用した場合に 比ぺ曲線は大きく左に寄り, ビードの割れ発生傾向は大 きくなる. すなわち展開角度 $10^{\circ}$ では $0.052 \sim 0.064 \% \mathrm{P}$ （P３ない P4 鋼）より曲線の立上りが見られ，また $15^{\circ}$ では $0.041 \%$ P (P 2 鋼) で, すでに約 $90 \% の$ 割れ率 を示した.なお非酸化線状破面の存在については前項の 場合と同様であるが，乙れがほぼ100\%の場合ああった．

\section{2 .3 ステンレス鋼を母材とする場合との比較}

高マンガン鋼および $17 \mathrm{Cr}-7 \mathrm{Ni}$ 型ステンレス鋼 (AISI 301 型) を母材とし， $16 \mathrm{Mn}-16 \mathrm{Cr}$ (No. 1b), $19 \mathrm{Cr}-9 \mathrm{Ni}$ および $25 \mathrm{Cr}-20 \mathrm{Ni}$ 棒を用いて溶接した場合の展開角度 と割れ率の関係を Fig. 5 に示した。

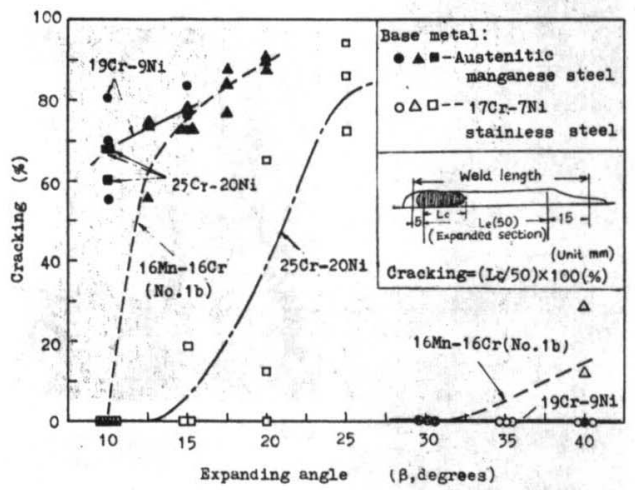

Fig. 5 Cracking susceptibility of bead weld deposited on austenitic manganese steel of normal silicon and phosphorus content and $17 \mathrm{Cr}-7 \mathrm{Ni}$ stainless steel (AISI 301) with $16 \mathrm{Mn}-16 \mathrm{Cr}, 19 \mathrm{Cr}-9 \mathrm{Ni}$ and $25 \mathrm{Cr}$ $20 \mathrm{Ni}$ electrodes

Fig. 5 で溶接金属の割れ発生傾向は, 使用した溶接 棒の型式によってかなり異なっているが，高マンガン鋼 を母材とするときは，ステンレス鋼を母材とする場合よ りもはるかに割れ発生傾向が大きい. たとえば高マンガ ン鋼を母材とするときは $16 \mathrm{Mn}-16 \mathrm{Cr}(1 \mathrm{~b})$ 棒では展開角 度 $12.5^{\circ}, 19 \mathrm{Cr}-9 \mathrm{Ni}$ 棒では $10^{\circ}$ ですでに約 $70 \%$ の割れ率 を示すのに対し， $17 \mathrm{Cr}-7 \mathrm{Ni}$ ステンレス鋼を母材とする ときは $16 \mathrm{Mn}-16 \mathrm{Cr}(1 \mathrm{~b})$, および $19 \mathrm{Cr}-9 \mathrm{Ni}$ それぞれ $30^{\circ}$ および $40^{\circ}$ で割れを生じていない.

上記の 2 種の溶接棒の場合, 母材が高マンガン鋼と $17 \mathrm{Cr}-7 \mathrm{Ni}$ ステンレス鋼とでこのように溶接金属の高温 割れ発生傾向が異なるのは, 前者では溶接金属のC含量 が約 $0.6 \%$ と高く, 完全オーステナイト組織となるのに 対し後者の場合は約 $0.1 \%$ と低く, フェライトインジケ
ーターで $16 \mathrm{Mn}-16 \mathrm{Cr}(1 \mathrm{~b})$ 棒使用の場合およそ1.5 2.5 \%，また $19 \mathrm{Cr}-9 \mathrm{Ni}$ 棒では $2.5 〜 5.0 \%$ のフェライトを 含むことが大きな理由として考えられる.

ステンレス鋼を母材とするときも，完全オーステナイ 卜組織を呈する $25 \mathrm{Cr}-20 \mathrm{Ni}$ 棒による溶接金属では, 16 $\mathrm{Mn}-16 \mathrm{Cr}$ および $19 \mathrm{Cr}-9 \mathrm{Ni}$ 棒使用の場合に比へ, 溶接 棒のP含量が低いにもかかわらず，かなり割れ易くな る.しかしとの場合も高マンガン鋼母材と $16 \mathrm{Mn}-16 \mathrm{Cr}$, $19 \mathrm{Cr}-9 \mathrm{Ni}$ および $25 \mathrm{Cr}-20 \mathrm{Ni}$ の各棒による溶接金属の 割れ発生傾向よりはかなり低い. この場合の割れ発生傾 向の差には前述のフェライトは無関係とみなされ, 従っ て両母材間の C含量の差の影響が大きいむのと考えられ る. ただし $25 \mathrm{Cr}-20 \mathrm{Ni}$ 型など $\mathrm{Cr}-\mathrm{Ni}$ 系のオーステナ イト溶接金属では, Cはその含量がかなり高くとも, 溶 融池の流動性を増し, その結果 Silicate のスラグの膜 が消滅するので, ミクロ割れの防止にむしろ有効とする いくつかの実験結果がある ${ }^{3)}$.

なお高マンガン鋼母材と P 含量の低い $16 \mathrm{Mn}-16 \mathrm{Cr}$ （No. 1a）棒とを組合せて使用するときは，困には省略 したが, 高マンガン鋼母材と P 含量の高い $16 \mathrm{Mn}-16 \mathrm{Cr}$ （No. 1b）棒を組合せた場合と，ステンレス鍮母材と $25 \mathrm{Cr}-20 \mathrm{Ni}$ 棒を組合せた場合の中間的な割れ発生傾向 を示した。

なおここに用いた高マンガン鋼は鋳造材，またステン レス鋼は圧延材で，乙れによる母材の不純物の分布状態 の差などが，ビードの割れ発生傾向にも多少の影響をお よぼしているてとも考えられる。

\section{3 Si および P のミク口的分布}

$\mathrm{Si}$ 含量が高く $\mathrm{P}$ 含量の低い $\mathrm{Si} 7$ 鋼, および逆に Si 含量が低く $\mathrm{P}$ 含量の高い P6 鋼を母材とする溶接金属の

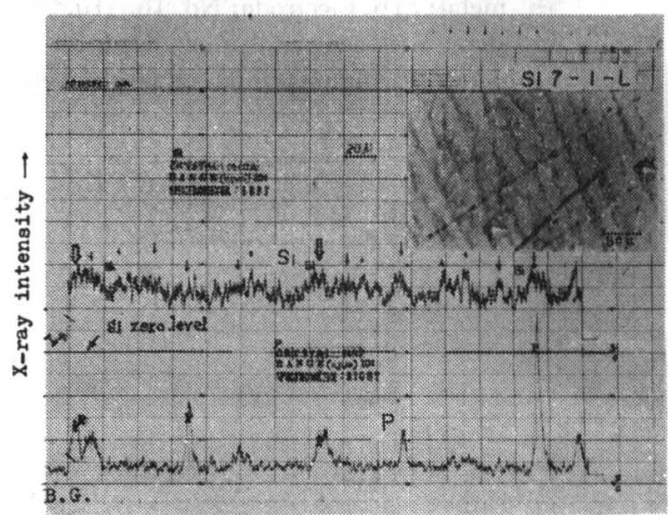

Fig. 6 Distribution of silicon and phosphorus in weld deposit (1).

Electron probe X-ray microanalysis (Fig. 6-9). Base metal: $\mathrm{Si} 7(1.85 \% \mathrm{Si})$, Electrode: $16 \mathrm{Mn}-16 \mathrm{Cr}$ (No. 1a). 


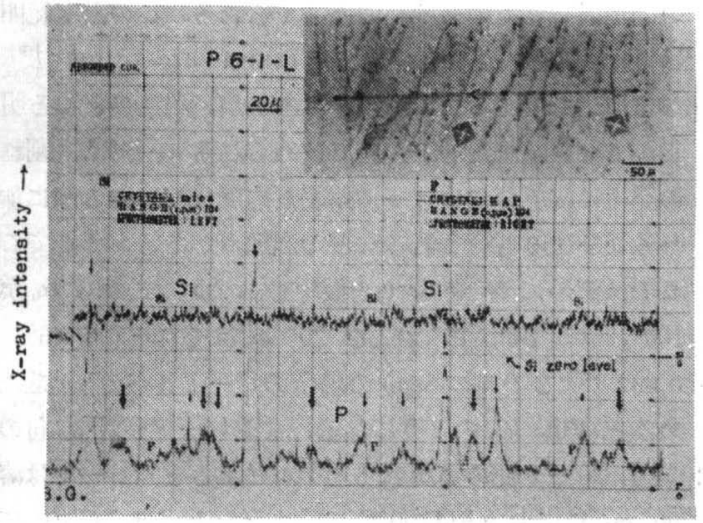

Fig. 7 Distribution of silicon and phosphorus in weld deposit (2).

Base metal: P6 $(0.086 \% \mathrm{P})$, Electrode: 16 Mn-16 Cr (No. 1a)

XMA による線分析の結果を Fig. 6 および 7 に示し た.これらはビード横断面の下半分のほぼ中央を走査し た例で，その位置は図中の顕微鏡写真に矢印を入れたコ ンタミネーションの線として示されている.

\section{$3 \cdot 3 \cdot 1 \mathrm{Si}$ の分布}

$\mathrm{Si} 7$ 鋼における $\mathrm{Si}$ の特性 X $\mathrm{X}$ 線の平均強度 (Fig. 6) は, P6 鋼の場合 (Fig. 7) に比べて当然ながらかなり 高いが, 各セルデンドライト内の変動もやや大きい. 一 般に隣接 セルデンドライトの境界（細い下向の矢印の 先）および写真では明瞭を欠くが, 結晶粒界（2本の太 い矢印の先）付近で高くなっている. ただしつぎに述ぺ るPの場合のような強いピークは認められない.

\subsubsection{Pの分布}

P含量の高い P6 鋼 (Fig. 7) の場合は, P含量の低 い Si 7 鋼 (Fig. 6) に比べ, Pの特性 X 線の強度レペ

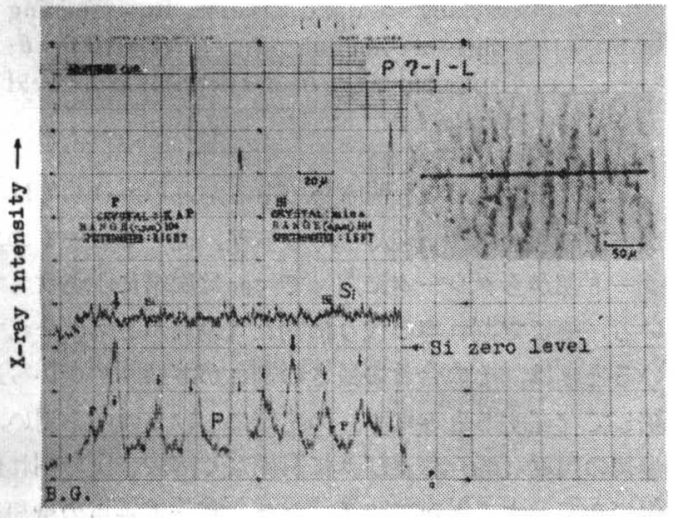

Fig. 8 Distribution of silicon and phosphorus in weld deposit (3).

Base metal: P7 $(0.276 \%$ P), Electrode: 16 Mn-16 Cr (No. 1a)
ルは当然高い. Si 7 鋼の場合にも, 結晶の粒界のみな らずセルデンドライトの境界の一部に P の強度にピーク が認められるが, P6 鋼の場合はかなり顕著になる.す なわち P の偏析物が結晶の粒界およびセルデンドライト の境界に存在し, ビームがこれに当ると高いX線強度が 得られる. これは P含量のいちじるしく高い P 7 鋼を 母材とする溶接金属にとくに顕著である. これを Fig. 8 に示す.

\section{$3 \cdot 3 \cdot 3$ 母材の P の偏析について}

P 7 鋼の場合, 母材の結晶粒界の 3 重点にしばしば大 きな P の㾫析物が存在するととはさきの報告1)で示した が,さらにこの種のPの偏析物について線分析した結果 を Fig. 9 に示す. この場合のPの特性 $\mathrm{X}$ 線強度はきわ めて高く (Full scale : $10^{5}$ c.p.m., Fig. 6, 7 および 8 の場合は $10^{4}$ c.p.m.), また Mn の強度も粒内よりかな り高い. 逆に $\mathrm{Fe}$ の強度は粒内よりあかなり低くなって おり, C, S, As, Sn は一般の結晶粒内の值とほとんど 差がない.

線分析の結果から各元素の濃度を求めると, $\mathrm{Fe}: 58$, Mn : 26, P : 11.2, S : 0.10, Si : 0.42(\%) となった. なお，これらは吸収補正を Philiber，原子番号補正を
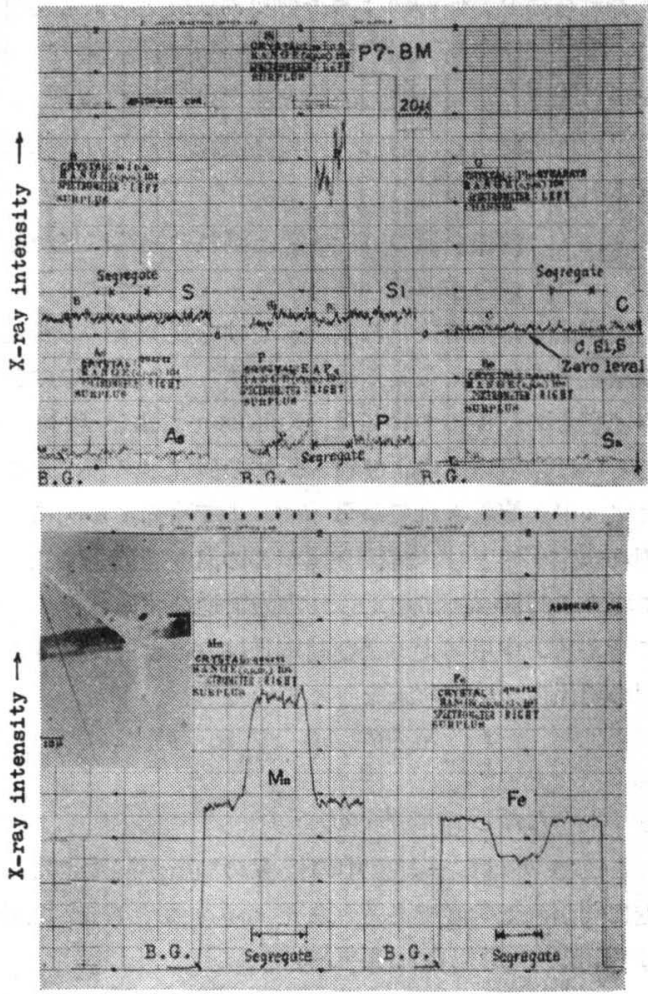

Fig. 9 Distribution of some elements in phosphorus-rich segregate observed in base metal, P7, 
Poole and Thomas の方法 ${ }^{5} に よ り$ 行なった一回の補正 の結果である.

ここで別のPの偏析物について求めた $\mathrm{P}, \mathrm{Si}, \mathrm{S}, \mathrm{Fe}$ および Mn の各特性 $\mathrm{X}$ 線の強度分布を Photo, 6 に示 した. $\mathrm{P}, \mathrm{Fe}$ および $\mathrm{Mn}$ の強度変化については線走査 の結果と一致するが, Si は P の痈析物内で局部的に高 くなっているようである. S についても同様な傾向が認 められる。
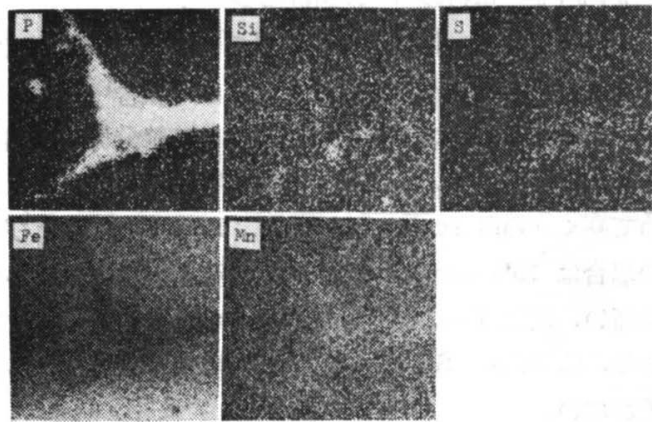

Photo. 6 Characteristic X-ray images of phosphorus-rich segregate observed in base metal, P7

これらのPの偏析物は熱影響部割れを促進するととも に, 溶接により再溶融し, さらに Mn の他 $\mathrm{Cr}$ を含み, 前項のように溶接金属の隣接セルデンドライト間および 結晶粒界に偏析し，溶接金属の高温割れの有力な原因之 なるあのと考えられる。

\section{4 溶接金属の $\mathbf{P}$ 当量と割れの終端に加わる 逆ひずみ量}

展開式すみ肉溶接割れ試験における展開条件の変化と 試験ビードに加えられる強制逆ひずみ量, あるいはひず み速度との関係については, Rollason および Roberts ${ }^{6)}$ あるいは中根博士および村本氏7) の研究がある. ここで はビードが溶着されてから $T^{\circ} \mathrm{C}$ まで冷却する間に高温 割れが生ずるとし，溶接金属がこの温度範囲を冷却する に要する時間 $t_{T}$ に加えられる強制逆ひずみ $\varepsilon_{T}$ につい て考える. 中根博士および村本氏は $\varepsilon_{T}$ と展開条件との 間の関係について次式を与えている7).

$$
\begin{aligned}
& \varepsilon_{T}=\left\{\sin \frac{\alpha_{0}+\theta+\omega t_{T}}{2} / \sin \frac{\alpha_{0}+\theta}{2}\right\}-1 \\
& \text { ただし } 0 \leqq \theta+\omega t_{T} \leqq \beta
\end{aligned}
$$

ここで $\theta$ はビード途中の任意の箇所が溶接されるま でに開かれた角度である. また $\alpha_{0}, \omega$ および $\beta$ の記号

は Table 3 の場合と同一とする.

ここで $t_{T}$ の值が問題となるが, 高温割れを凝固割れ に限ると, その発生の危険温度範囲（脆性領域）はその 合金の公称液相温度からこれに含まれる低融点の不純物
の固相温度までのある範囲と考えられる．との温度範囲 は将来適切な方法, たとえば Trans-Varestraint 法8) などによって明らかにすべきであるが，現在のところ明

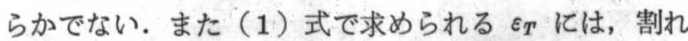
の発生に関係のないビードがまだ溶融状態にある間に加 わる逆ひずみあ含まれるなどの問題点がある.そこでて こでは簡単に $t_{T}$ を $5 \mathrm{sec}$ と仮定し, (1) 式から $\alpha_{0}$ が $100^{\circ}, \beta$ が $10^{\circ}, 15^{\circ}$ および $20^{\circ}\left(\omega\right.$ はそれぞれ $0.46^{\circ}$, $0.69^{\circ}$ および $\left.0.92^{\circ} / \mathrm{sec}\right)$ の場合のビード各点の $\varepsilon_{T}$ を求 めると Fig. 10 のようになる.なおビード長手方向の 中央, ルート部の実測熱サイクルによると, ピート゚は溶 着 $5 \mathrm{sec}$ 後におよそ $1100^{\circ} \mathrm{C}$ に，またたとえば $1400^{\circ} \mathrm{C}$ に ある部分はおよそ $1000^{\circ} \mathrm{C}$ まで冷却する. また Fig. 10 で溶接開始点から約 $50 \mathrm{~mm}$ を超えると $\varepsilon_{T}$ が急速に小 さくなるのは $5 \mathrm{sec}$ 以内に展開が終了するためである.

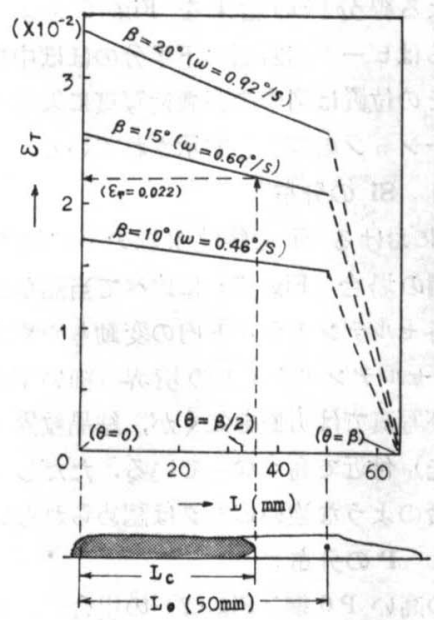

Fig. 10 Relation between strain imposed on bead weld in temperature range critical to hot cracking $\left(\varepsilon_{T}\right)$ and distance from starting point of welding (L). $\quad \alpha_{0}=100^{\circ}, \theta$ : Expanded angle before deposition of weld metal.

さて（1）式からあ明らかであるが, Fig. 10 では $\omega$ が一定の場合は $\theta$ が大きくなる程, 従ってビードのス タート部からクレータに向って $\varepsilon_{T}$ は次第に小となって いる. そこで割れ率の代りに割れ（割れが 2 個に分れて いるときは, その合計の長さの割れが溶接開始点から連 続して存在するとみなす）の終端における $\varepsilon_{T}$ を用い, 最初の角度 $\left(\alpha_{0}\right)$ および $\beta$ に関係なく溶接金属の割れ発 生傾向を示すととができる.ただしビード各点の冷却速 度わよび溶込み率は一定と仮定する。

いま母材, 溶接棒および展開角度 ( $\beta$ ) の各組合せに おける割れの長さ $\left(L_{c}\right)$ の平均値を求め, これより Fig. 
10 の例（展開部の割れの長さ $35 \mathrm{~mm}$ (割れ率 $70 \%$ )， $\beta$ が15ㅇ.の場合を示す）に従って割れの終端における $\varepsilon_{T}$ を求める: ただし Fig. 3 および 4 において数回の繰返 しのうち割れの長さに0または $50 \mathrm{~mm}$ 以上の值を含ま ぬ15条件の場合（この場合割れ率を $r(\%)$ 之する之 $0<$ $r<100)$ だけを検討の対象とする.つぎに溶込み率を50 \%（実測したビード中央部の值はおよそ $47 \%)$ として， Table 1 および 2 に示したそれぞれ母材括よび溶着金属 のPおよび Si 含量から，ビードすなわち溶接金属のP および Si 含量を計算する。さらにこれらの值をるとに 上記の15の場合に該当する母材と溶接棒の各組合せに対 し次式により $\mathrm{P}_{e q}$ を求める.

$$
\mathrm{P}_{e q}=\% \mathrm{P}+1 / 40 \times \% \mathrm{Si}
$$

Fig. 11 はこのようにして求めた $\varepsilon_{T}$ よ $\mathrm{P}_{e q}$ との関係 を示す屯ので， $P_{e q}$ の增大とともにお抬む的直線的に $\varepsilon_{r}$ が小さくなる.すなわち割れが生じ易くなる状態が $\beta$ に関係なく示されている.なお（2）式に执いて $\mathrm{P}_{\epsilon q}$ における Si の係数には, 最小 2 垂法で求めた 0.027 に 近い1/40を採用したが，上記の $0<\gamma<100(\%)$ の条件 の下では溶接金属の $\mathrm{Si}$ 含量の高い場合の有効なデータ が少ないので, Si の係数にはな検討の余地があるあ のよ考える.

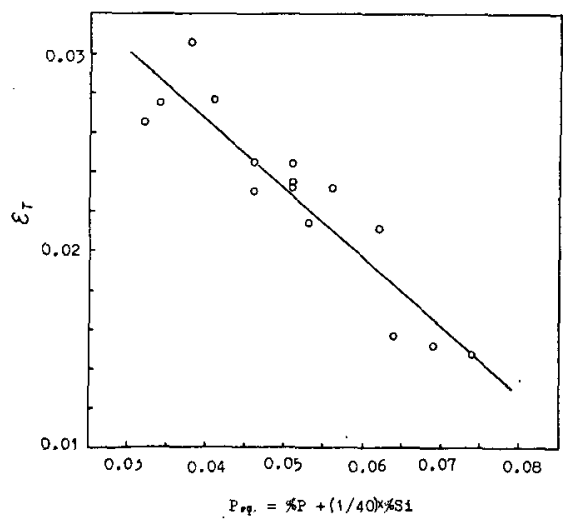

Fig. 11 Relation between strain imposed on weld metal in temperature range critical to hot cracking $\left(\varepsilon_{T}\right)$ and $P$ equivalent.

\section{4. 結}

論

高マンガン䥡母材の Si 含量を0.18〜1.85\%，あるい は P含毁を $0.035 〜 0.086 \% の$ 範用に変えた場合の， 2 種 の $16 \mathrm{Mn}-16 \mathrm{Cr}$ 溶接棒による溶接金属わよび母材熱影響 部の割れ発生傾向を求め, 両元素の影響を比較した。さ らに通常のPおよび $\mathrm{Si}$ 含量の茼マンガン鋼母材之 16 $\mathrm{Mn}-16 \mathrm{Cr}$ 型他 2 種の溶接棒を用いた溶接金属の割れ発 生傾问を， $17 \mathrm{Cr}-7 \mathrm{Ni}$ ステンレス銅を母材とする場合と

\section{比較した。}

（1）母材の Si 含量を変え， $16 \mathrm{Mn}-16 \mathrm{Cr}$ 型溶接棒 を用いたスリット型溶接割れ試験では，融合線付近の溶 接熱影響部に微細な少数の割れを認めることがあるが， これらは $1.85 \% \mathrm{Si}$ でも溶接金属へほとんど進展しな い. これに対じ母材のP含量を変えた前回の実験では， $0.065 \sim 0.085 \% \mathrm{P}$ に扔いて熱影響部から溶接金属へ明膫 な割れを生じている。

（2）展開式すみ肉溶接割狆試験では，母材の $\mathrm{Si}$ お よび $\mathrm{P}$ 含量の增大によって，16Mn-16Cr 溶接棒による 溶接金属の割れ発生傾向は明らかに大となる。この場合 供試溶接棒におけるP含量の差は上記の割れ発生傾向に 大きな影響を与えている。

（3）通常のPおよび Si 含量の高マンガン鋼を母材 とする展開式すみ肉溶接割れ試験では， $16 \mathrm{Mn}-16 \mathrm{Cr}, 19$ $\mathrm{Cr}-9 \mathrm{Ni}, 25 \mathrm{Cr}-20 \mathrm{Ni}$ のいずれの型の溶接棒を使用する あ， $17 \mathrm{Cr}-7 \mathrm{Ni}$ ステンレス鋼を母材とする場合に比べて， 溶接金属の割れ発生傾后はいちじるしく大きい.とれに は溶接金属のC含量およびてれに大きく左右されるフェ ライト量の差が影響しているものと考えられる。

（4）X線マイクロアナライザーによる分析の結果, 母材のP含量の高い場合，溶接金属の杜状晶の粓界，あ るいは隣接セルデンドライトの境界付近にPの强い偏析 を認める、母材の Si 含量の高い場合も Si の偏析に類 似の傾向を認めるが，Pの場合のような著しい偏析は認 められない。

（5）展開式すみ肉溶接割れ試験の場合, 割れ率の代 りに，ビードの割れの終端が，高輀割れを生じ易い温度 範囲を椧却する間に受ける逆ひずみ量 $\varepsilon_{T}$ を用い，また 溶接金属のPおよび $\mathrm{Si}$ 含量の代りに $\mathrm{P}_{B q}=\% \mathrm{P}+1 / 40$ $\times \% \mathrm{Si}$ を用い， $\mathrm{P}_{\varepsilon q}$ の増大ととむに $\varepsilon_{r}$ が低下する， すなわちビードの割㞦発生傾何が增大する状態を展開盾 度 $\beta$ に関係なく示した.

本奏験を行なうに当り，ステンレス鋼に対する比較試 験の一部については日本溶接協会溶接棒部会技術委員会 (昭和 45 年度共研第 2 分科会)，X線マイクロアナライ ザーによる分析については铁道技術研究所無機化学研究 室，また高マンガン龬陚験材の製作については大同製鋁 K K の御援助を得た．ここに関係各位に対し厚く感謝の 意を表する.

\section{参考文献}

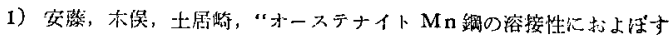

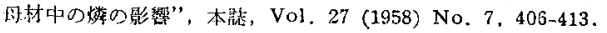

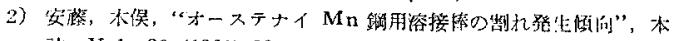

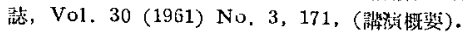


3) J.C. Borland and R.N. Younger, "Some Aspects of Cracking in Welded Cr $-\mathrm{Ni}$ Austenitic Steels", British W.J. Vol. 7 (1960) No, 1, 33-36.

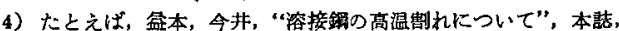
Vol. 39 (1970) No, 6, 565-575.

5）市ノ川，“X線マイクロアナライザーに上る定胃分析”，応用物理， Vol. 34 (1965) No, $12,858-873$.

6) E.C. Rollason and D.F.T. Roberts, "Operating Data for the Mirrex Hot-Crack Testing Machine", British
W. J. Vol. 1, (1954) No. 10, 441-447.

7) K. Nakane and T. Muramoto, "Study on the Reverse Bend Severity Weldability Tést -A Modified Murex Hot-Crackig Test", Rail. Tech. Res. Rep., No. 114 (1960).

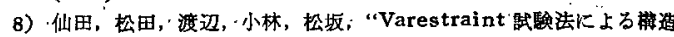
材料の高混割れの研究”。，溶接学会全国大会皘演概要（第 8 集， 1971), $265 \sim 270$.

\section{ジンポジウム案内}

"Welding Equipment, Technologies and Materials for Metturgical Industry"

（冶金工業にお污る溶接の設備，技術，材料）

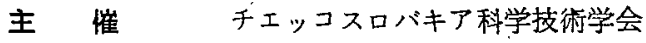

溶接技術研究所

日 時

1972年9月11日〜16日（9月16日は International Engineering Brno Fair 1972を見学します)

問合先 Dom techniky SUTS

Kocelova 17, Bratislava

Czechoslovakia 